Acta Crystallographica Section A

Foundations of Crystallography

ISSN 0108-7673

Received 7 October 2009

Accepted 13 October 2009

(C) 2010 International Union of Crystallography

Printed in Singapore - all rights reserved

\section{The birth of the European Crystallographic Committee (ECC) and of the European Crystallographic Meetings (ECMs)}

\author{
André Authier \\ Institut de Minéralogie et de Physique des Milieux Condensés, Université P. et M. Curie, \\ 4 Place Jussieu, F-75055 Paris, France. Correspondence e-mail: aauthier@wanadoo.fr
}

\begin{abstract}
At ECM25, held in Istanbul, Turkey, on 16-21 August 2009, the 25th anniversary of the European Crystallographic Meetings was celebrated. In this article, it is recalled how the idea of coordinating international meetings on crystallography in Europe was put forward at a meeting held in Manchester, UK, in April 1971, and it is explained how the European Crystallographic Committee was established for that purpose during the Ninth IUCr Congress in Kyoto, in 1972. The organization of the first European Crystallographic Meeting, ECM1, held in Bordeaux, France, in 1973, is briefly described and the evolution of the main topics of the scientific programme from that time to ECM 25 is commented upon.
\end{abstract}

\section{Introduction}

During 16-21 August 2009, a memorable and very well organized ECM25 was held in the Military Museum of the beautiful city of Istanbul, Turkey, with an attendance of about 800 participants. Besides a most interesting scientific programme and a rich cultural programme, there was a Ceremonial Meeting to celebrate the 25th anniversary of the European Crystallographic Meetings, the first of which, ECM1, was held in Bordeaux, France, in 1973. The aim of the present paper, based on remarks made by the author during that Ceremonial Meeting, is to recall how all this came about.

\section{The first European Crystallographic Committee}

It all started in 1969.

Since the first Congress of the International Union of Crystallography in 1948, the IUCr congresses, held every three years, rapidly increased in size and the Executive Committee feared that they would become excessively large and cumbersome. An Advisory Panel was set up by the General Assembly at the Seventh General Assembly held in Moscow, in 1966, to advise on future Congresses [Acta Cryst. (1967), 23, 1115-1124]. Following its recommendations, the Executive Committee in 1968 accepted that the triennial congresses should be continued and appointed a permanent SubCommittee on the Union Calendar to be responsible for coordination and encouragement of Union-sponsored or cosponsored meetings of appropriate size and good scientific content [Acta Cryst. (1969), A25, 719-731]. It is in this spirit that preliminary informal discussions took place among European crystallographers during the Eighth IUCr Congress held in Stony Brook, USA, in 1969, to see if something could be organized within Europe. On 14-16 April 1971, a meeting on 'Current Research in Crystallography' was held in Manchester, UK, later to be labelled 'ECM0', one of six Conferences and Schools sponsored by the IUCr for that year. In a letter dated 21st April 1971 to A. Linek, then member of the IUCr Executive Committee and Chair of the Calendar Sub-Committee, Stephen Wallwork, at the time Secretary of the Crystallography Group of the UK Institute of Physics, indicated that it was a very good conference with about 200 participants and nine invited speakers out of which seven were from the Continent' and that it was made possible by a grant from the IUCr (Fig. 1).

In the same letter, Stephen Wallwork informs A. Linek that 'a very useful discussion took place about the possibility of forming a European Crystallographic Organization' (in a recent communication to me, he recalls that it was on the evening of 14th April). My own memory is that the initiative was strongly encouraged by the then President of the IUCr, Professor André Guinier. In his letter to A. Linek, Stephen Wallwork added: 'all but the Russians felt that there was the need for some informal organization and Professor Authier is going to circulate a letter to all European countries inviting their collaboration. He will collect and distribute information about crystallographic meetings in Europe and in this he will, of course, collaborate closely with you. It is hoped that this will lead to some coordination of meetings to avoid clashes of topics and dates and to the designation of about one meeting per year as an international meeting. The aim is to make it easier for us to take part in each other's conferences and if this works well there could (be) a reduction in the total number of meetings'. This defines perfectly well the guidelines followed by the future European Crystallographic Committee. Stephen Wallwork had already been involved in the setting up of the 


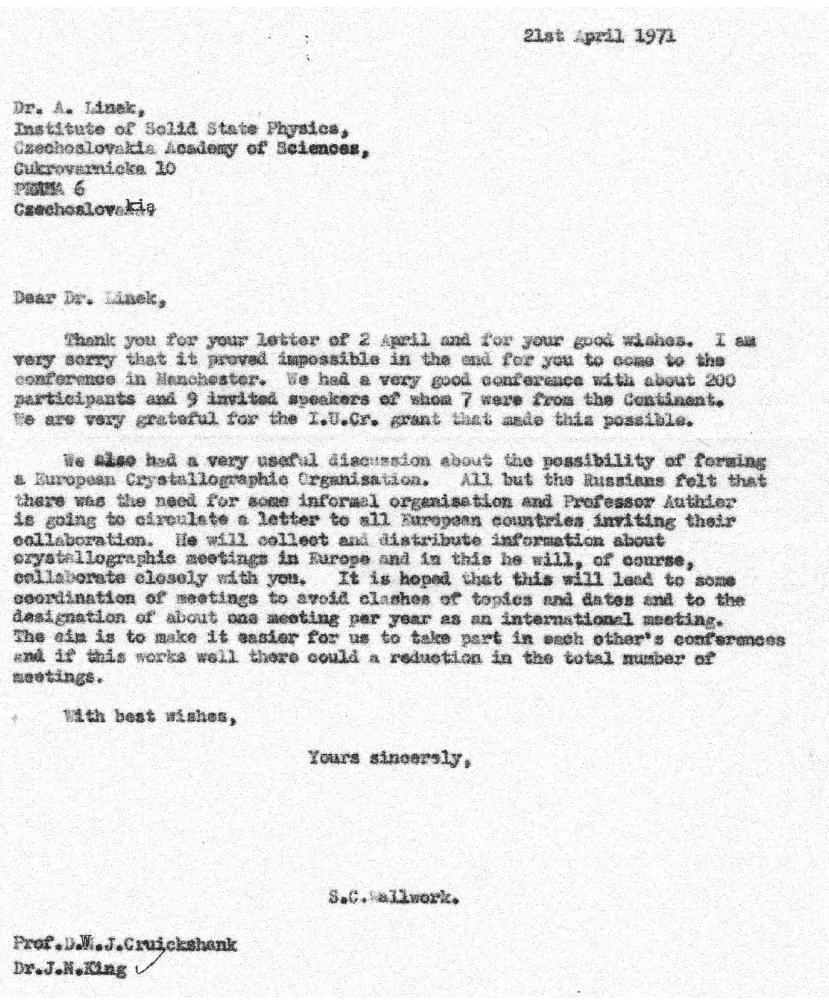

Figure 1

Letter from S. C. Wallwork, Secretary of the Crystallography Group of the UK Institute of Physics, to A. Linek, Chairman of the IUCr Calendar Sub-Committee (courtesy M. Dacombe).

United Kingdom Crystallographic Council with similar aims for coordinating crystallographic meetings within the UK, but without arranging the meetings themselves.

Following the Manchester meeting, I contacted the secretaries of all the European National Committees explaining the objectives of the initiative as well as my own views on how to achieve them and asking them to designate a representative for a meeting to be held during the Ninth IUCr Congress (Kyoto, Japan, 26 August - 7 September 1972). The first action taken was, however, to organize charter flights from different places in Europe to Kyoto and I remember very well having several travel agencies in different countries bidding against each other, the winner being an agency in Cologne, Federal Republic of Germany. Dirk Feil, the Dutch representative, recalls: 'We were all impressed by the fact that European cooperation could facilitate so much. Travelling together on such a long distance flight made it possible to exchange ideas and to organize new things. For myself the cooperation with respect to the travel to Japan was a great stimulus for European Crystallography'.

The representatives of 19 or 20 European countries duly met in Kyoto and decided to constitute themselves as the European Crystallographic Committee (ECC) with myself as chairman. There is no record of the list of the members present, but Dirk Feil (The Netherlands), Frank Herbstein (Israel) and Olga Kennard (UK) remember participating and the list of ECC members as it appears in the book of abstracts of the first European Crystallographic Meeting in Bordeaux in
Table 1

Membership of the European Crystallographic Committee at ECM1 in Bordeaux (1973) (courtesy M. Hospital).

\begin{tabular}{ll}
\hline Country & Representative \\
\hline Belgium & Gilbert Jacobs \\
Czechoslovakia & Alan Línek \\
Denmark & Ingrid Kjøller-Larsen \\
Finland & Martti Heikki Kantola \\
Federal Republic of Germany & Kurt Moliere \\
France & André Authier (Chairman) \\
German Democratic Republic & Otto Brümmer \\
Hungary & Lehel Zsoldos \\
Israel & Frank Herbstein \\
Italy & Mario Mammi \\
The Netherlands & Dirk Feil \\
Norway & Christian Rømming \\
Poland & Kazimierz Łukasiewicz \\
Portugal & Jose Lima de Faria \\
Spain & Sagrario Martinez-Carrera \\
Sweden & Sixten Abrahamsson \\
Switzerland & Jack Dunitz \\
United Kingdom & Olga Kennard \\
USSR & Valentin Simonov \\
Yugoslavia & Drago Grdenic (Stjepan Šcavničar)† \\
\hline
\end{tabular}

$\dagger$ Drago Grdenic was not present in Bordeaux and was replaced by Stjepan Šcavničar as the Yugoslav representative.

1973 is given in Table 1. At ECM25 there was a meeting of young crystallographers, with a view of forming eventually a Special Interest Group. In 1972, all of us were young and enthusiastic crystallographers!

Our main objective was to coordinate in a concerted fashion the dates and topics of meetings on a European level in different countries, each country retaining, to use the words of Olga Kennard, President of the ECC from 1975 to 1981 (Fig. 2), 'its national identity and organizing the meeting in its own style and tradition so that the ECMs benefited from the rich cultural variety of Europe'. And this has been achieved in all the successive ECMs and is beautifully exemplified by the success of ECM25. Our original aim had been that the meetings could be held alternately in Western and Eastern Europe. It must be remembered that these were the days of the cold war and travelling abroad was very difficult for people from

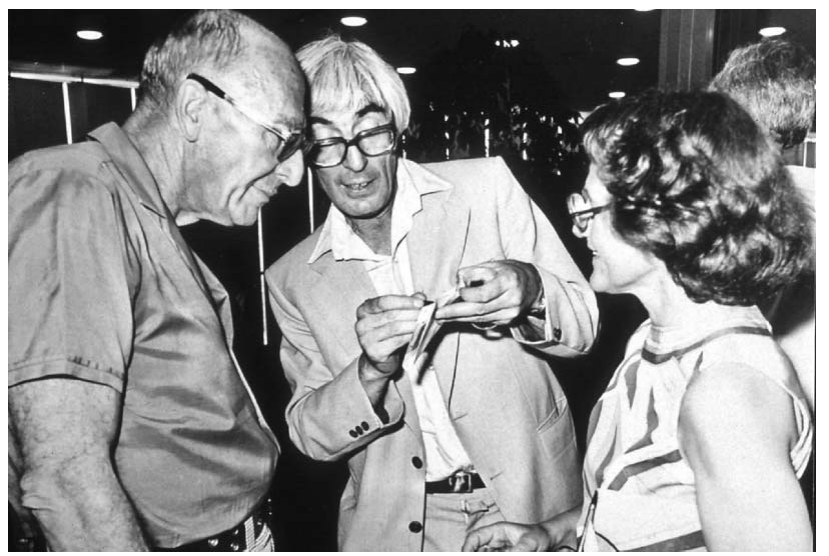

Figure 2

A. I. Kitaigorodskii, J. D. Dunitz and O. Kennard (President of the ECC, 1975-1981) at the Xth IUCR Congress, Amsterdam, 1975 (courtesy O. Kennard). 
Eastern countries, both for political and financial reasons. We thought that the ECC and the ECMs could provide a sort of umbrella that would help crystallographers from Eastern countries to go out in the West. In this we succeeded as is well remembered even today by those who lived through these hard times and who say that it did provide a great help. If the first two ECMs did follow the alternation, ECM1 in Bordeaux, France, ECM2 in Keszthely, Hungary, it was, however, difficult to keep it up regularly but the main thing is that the principle was agreed upon by all.

Constituting the ECC, however, was not a straightforward affair, essentially because of the strong reluctance, to say the least, of the Soviet representative to the project, as already mentioned by S. C. Wallwork in his 1971 letter to A. Linek. Boris Kamenar (Fig. 3) remembers it very well: 'during the 8th IUCr Congress held in Stony Brook in 1969, I, as a Yugoslav representative, was under their pressure. Their representatives tried to persuade me to be against the constitution of any European organization but, instead, to establish an East European crystallographic organization. I was adamantly against such a project and they finally gave up the whole idea' The reasons for the Russian opposition were manifold. The Soviet authorities were not happy with any organization that would facilitate the contacts between Eastern and Western European countries. They also objected strongly, for political reasons, to the inclusion of Israel. In Kyoto, I had tough discussions with the Russian member of the Executive Committee, Boris Vainshtein, with whom I was, in fact, on very friendly terms and, thanks to the resolute attitude of all the other European representatives, I managed to convince the Soviet representative to accept the establishment of the ECC.

One way to alleviate the concerns of the Soviet representative was to adopt a very loose and informal format for the ECC. This was, after all, one of the recommendations made by the participants to the meeting in Manchester, in 1971. We decided that there would simply be one member per country,

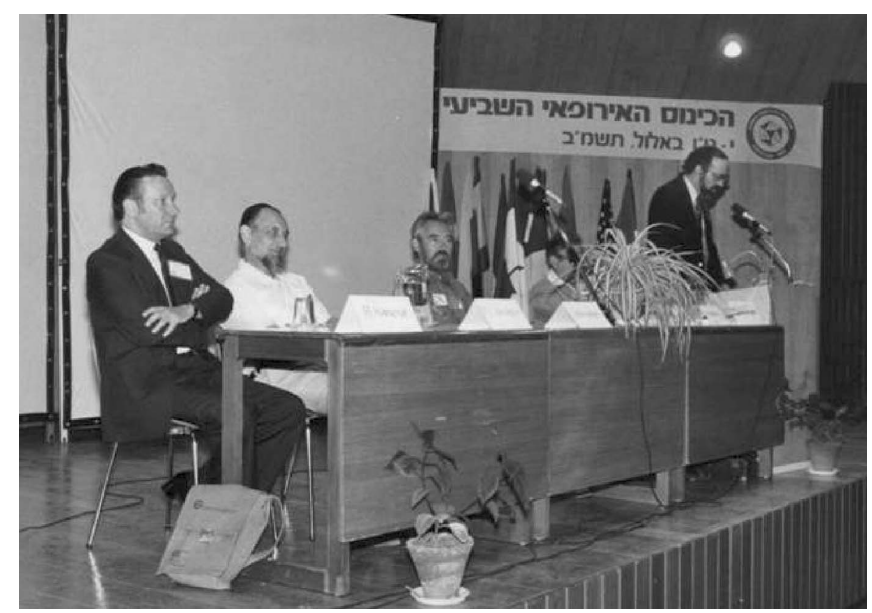

Figure 3

B. Kamenar (President of the ECC, 1981-1984), F. Hirshfeld, P. Beurskens (Secretary of the ECC, 1978-1984 and of the ECA, 19972000) and J. Bernstein (Vice-President of the ECC, 1994-1997 and of the ECA, 1997-2000) at the opening ceremony of ECM7, Jerusalem, 1982 (courtesy J. Bernstein).

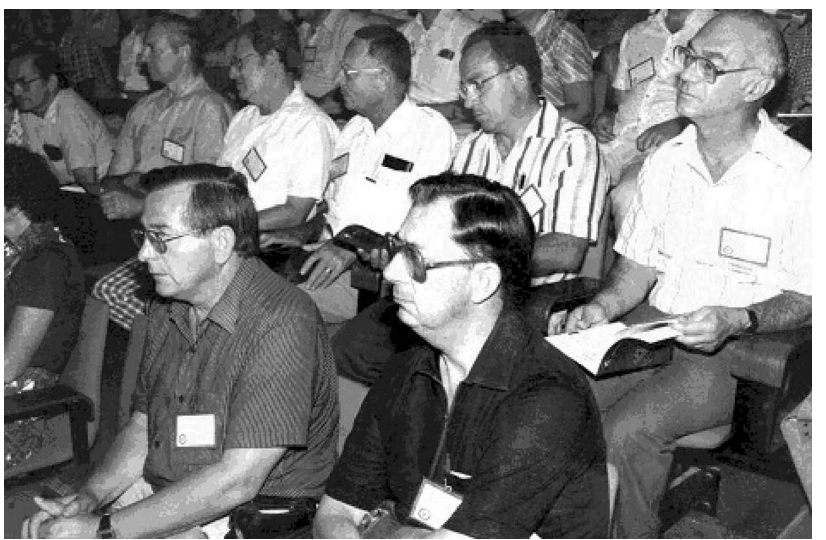

Figure 4

The audience at the opening ceremony of ECM7, Jerusalem, 1982, with A. Authier, first President of the ECC (1972-1975) at the front (courtesy J. Bernstein).

only one officer, the chairman (or president), no finances and that the sole objective would be to organize meetings. Once the principle of the ECC was accepted, the Russian crystallographers were active participants and they organized ECM12, in Moscow, in 1989.

As the years went by, the ECC became more and more formal, and this is probably a natural trend for all organizations. The positions of Vice-President and Secretary were introduced in 1978 and were held for the 1978-1981 triennium by B. Kamenar (Yugoslavia) and P. Beurskens (The Netherlands), respectively (Fig. 3). The ECC became a Regional Associate of the IUCr at the 11th IUCr congress in Warsaw in 1978, with J. Karle as the first IUCr representative. The organization of the ECC became much more formal when it was replaced in 1997 during ECM17 held in Lisbon, Portugal, by the European Crystallographic Association (ECA); the early history of the ECA is told by C. Lecomte (2002) and H. Fuess (2004). Back in the early 1970s, there was no need for such a formal status. We were also anxious not to create a body which in any way might have appeared as competing with the IUCr. This was, as we have seen, one of the concerns of the Russians. Of course, this fear disappeared with the designation of the ECC as a Regional Associate of the IUCr.

The initial inclusion of Israel in the ECC made it possible for Israel to organize ECM7 in Jerusalem in 1982 (Figs. 3 and 4) and paved the way for the inclusion of Egypt in 1990, South Africa in 1998, Turkey in 2001 and Morocco in 2002. The IUCr now has three Regional Associates (ACA, ECA and AsCA founded in 1987) and the ECA also represents Africa.

\section{The first European Crystallographic Meeting (ECM1)}

In order to best coordinate crystallographic meetings, the ECC decided in Kyoto that there should be only one international meeting in Europe per year, on every non-IUCr Congress year, as already planned at the Manchester meeting. The first one was organized by the Laboratory of Crystallography of Bordeaux University with Professor R. Gay as Chairman of the Organizing Committee and Dr J. Housty as 
Table 2

Invited lectures at ECM1 in Bordeaux (1973). Courtesy M. Hospital.

\begin{tabular}{ll}
\hline $\begin{array}{l}\text { G. S. Pawley (Edinburgh) } \\
\text { J. D. Dunitz (Zürich) }\end{array}$ & $\begin{array}{l}\text { Molecular lattice dynamics } \\
\text { Non-bonded interactions in organic molecules } \\
\text { A. Novak (Paris) }\end{array}$ \\
$\begin{array}{l}\text { Hydrogen bonds in solids } \\
\text { A. I Koscoigorodskii }\end{array}$ & $\begin{array}{c}\text { Application of non-bonded interaction functions } \\
\text { to solid solutions } \\
\text { Determination of the molecular packing by } \\
\text { potential energy calculations }\end{array}$ \\
E. Giglio (Rome) & $\begin{array}{c}\text { Consistent derivation of crystallographic, } \\
\text { spectroscopic and thermodynamic properties }\end{array}$ \\
S. Lifson (Rehovot) & $\begin{array}{c}\text { Electron density analysis by Fourier and } \\
\text { least squares }\end{array}$ \\
P. Coppens (Buffalo) & $\begin{array}{c}\text { Structure of the complex between pancreatic } \\
\text { trypsin inhibitor and trypsin: a stable } \\
\text { intermediate of peptide hydrolysis }\end{array}$ \\
R. Huber (Munich) &
\end{tabular}

the General Secretary (Fig. 5). The letter from the IUCr's Executive Secretary, J. N. King, announcing the offer of IUCr sponsorship to the meeting can be considered as the act of birth of the ECMs (Fig. 6).

There were about 500 participants and the scientific discussions extended over two full days and two half-days, with an excursion in the Bordeaux wine district in between. There were eight invited lectures (Table 2) and 18 sessions running three in parallel. This was before the introduction of microsymposia and poster sessions and the communications were still all oral at the time; poster sessions were introduced at ECM3 in Zürich in 1976 (Abrahams, 1977). The system adopted was not fully satisfactory; most chairmen used about half the allotted time for the session for a general introduction, which made the sessions more coherent, but left little time for each presentation. P. Coppens, in his report of the meeting (Coppens, 1974) noted, however, that the 'great many contributed papers were impressive by their variety, multitude and generally high quality'. He concluded that 'in Bordeaux, a serious attempt was made to eliminate the drudgery of a long incoherent succession of short contributed papers. Equally important, the atmosphere at the meeting was exciting, many new contacts were established and one came away with the feeling that continent-wide collaboration between crystallographers in Europe had received a boost which can only be beneficial'. This set off the spirit of future ECMs.

It is interesting to note the evolution of the topics from ECM1 in 1973 to ECM25 in 2009. The main topic then was molecular interactions, with two emerging topics, accurate

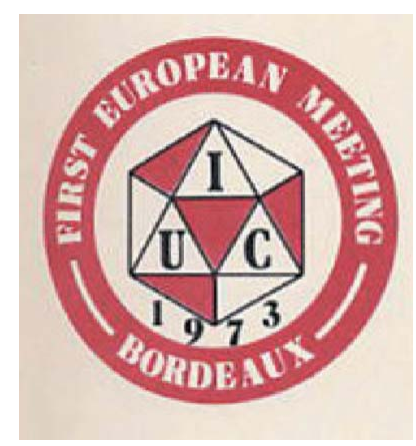

Figure 5

Logo of ECM1 (courtesy M. Hospital).

\section{INTERNATIONAL UNION OF CRYSTALLOGRAPHY}

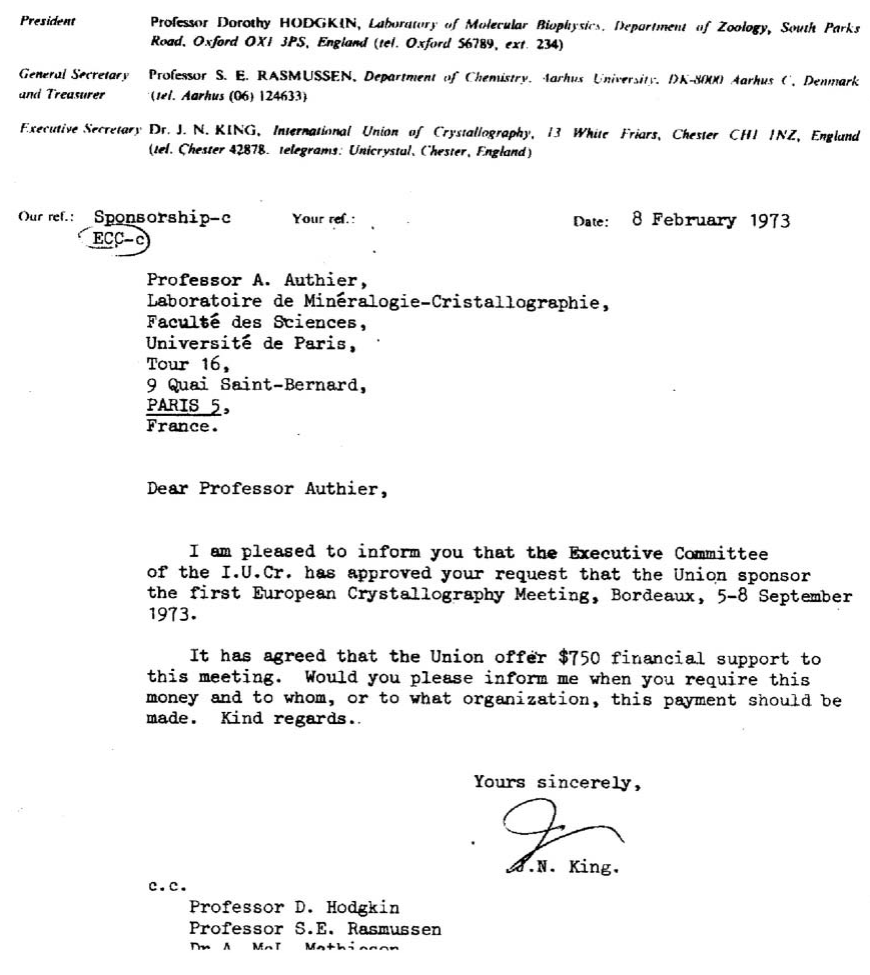

Figure 6

Letter from the IUCr Executive Secretary, J. N. King, about the sponsorship of ECM1 (courtesy M. Dacombe).

determination of electron densities and biocrystallography. For instance, for the latter topic, there were three sessions out of 18 and one invited lecture out of eight (by the future Nobel Prize winner, R. Huber) in 1973 while there were 14 Microsymposia out of 48 and five Keynote Lectures out of 16 in 2009 , showing the increase of the importance of that field in crystallography today.

\section{Conclusion}

It is very gratifying to see that the efforts spent in the early 1970s have been rewarded with such success. The ECA (formerly ECC) and the ECMs are now well established institutions. They have helped to bring together the crystallographers from all parts of Europe in difficult times and have been for the benefit of all ever since.

The author is grateful to Joel Bernstein, Dirk Feil, Frank Herbstein, Michel Hospital, Boris Kamenar, Olga Kennard, Valentin Simonov and Stephen Wallwork for sharing their souvenirs with him.

\section{References}

Abrahams, S. C. (1977). J. Appl. Cryst. 10, 75.

Coppens, P. (1974). J. Appl. Cryst. 7, 312-313.

Fuess, H. (2004). http://www.iucr.org/news/newsletter/volume-12/ number-1/guest-editorial.

Lecomte, C. (2002). http://www.rigaku.com/downloads/journal/ Vol19.1.2002/preface.pdf. 